\title{
Long-term changes in the benthic communities of the Pomeranian Bay (Southern Baltic Sea)
}

\author{
J. Kube ${ }^{*}$, F. Gosselck ${ }^{2}$, M. Powilleit ${ }^{1} \& J$. Warzocha ${ }^{3}$ \\ 'Institute of Baltic Sea Research, Seestraße 15, D - 18119 Rostock, Germany \\ 2Institute of Applied Ecology, Lindenweg 2, D-18184 Neu Broderstorf, Germany \\ 'Sea Fisheries Institute Gdynia, ul. Kollataja 1, PL - 81-332 Gdynia, Poland
}

\begin{abstract}
Long-term changes in the macrofauna of the Pomeranian Bay were studied by comparing survey data from the 1950s, 1980s, and 1990s. The study ared has undergone significant eutrophication during the period of investigation. Biomass of filter-feeding blvalves increased significantly. Spatial distribution patterns of several species have changed. Strong decreases in species richness were caused by oxygen depletion at stations deeper than $15 \mathrm{~m}$. Saduria entomon, Monoporeia affinis, and Pontoporeia iemorata vanished entirely between 1981 and 1993. Although a causal relationship between simultaneous increases of nutrient levels and macrobenthic biomass cannot be verified, cutrophication is proposed to be the rejor process affecting changes in macrofauna assemblages. In addition. changes in hydrography and climate increased trequency and severity of oxygen depletion events in the Pomeranian Bay since the mud 1980s.
\end{abstract}

\section{INTRODUCTION}

Several attempts have been made to explain long-term changes in the macrozoobenthos of the Baltic Sea. Severe biomass reductions or even macrofauna death were often observed below the halocline (Heip, 1995). A general change from bivalvedominated towards polychaete-dominated communities was documented in the deeper parts of the southern Baltic (Andersin et al., 1978; HELCOM, 1990). The oxygen concentration of the deepest water level had started to decrease by the end of the 19th century and fell to almost negligible concentrations in all deeper basins in the early 1990s. This anoxia has been attributed to both man-made eutrophication and climatic changes (e.g. Fonselius, 1972; Gargas et al., 1978; Gerlach, 1994).

Many authors have also described a significant increase in macrofauna biomass above the halocline as a consequence of higher food supplies (Pearson \& Rosenberg. 1978; Cederwall \& Elingren, 1980); Brey, 1986). However, since 1980 oxygen depletion has also caused strong fluctuations in the benthic biomass of several shallow bays during periods of strong stratification (Gosselck \& Georgi, 1984; Weigelt \& Rumohr, 1986). It is supposed that the observed remarkable changes in community composition were caused by an increase in organic inputs to the sediment due to eutrophication and a change of hydrographic conditions (Weigelt, 1991; Prena, 1994).

\footnotetext{
- Addressee for all correspondence.

D Biologische Anstalt Helgoland, Hamburg
} 
This paper describes long-term changes in the macrozoobenthic communities of the Pomeranian Bay (southern Baltic Seal by comparing the 1950s with the 1980s and 1990 s. The Pomeranian Bay is a shallow transition zone between the Oder Estuary and the deeper Arkona and Bornholm Basins (Fig. 1). Due to its topography and hydrography, recent macrofauna communities are influenced by both an increase in organic riverine loads and severe oxygen depletions in the deeper basins (Powilleit et al., 1995; Kube et al., 1996). The aim of our study is to discuss the long-term changes in the macrozoobenthos in relation to fluctuations and long-term trends in the environmentai conditions.

\section{MATERIAL AND METHODS}

We compared onginal data sets from studies carried out from 1955 to 1958 (Löwe. 1963), from 1980 to 1982 (Gosselck, 1985; Warzocha, 1995) and in 1993 (Powilleit et al. 1995). In all studies a heavy, $0.1 \mathrm{~m}^{2}$ Van Veen grab, a sieve with $1-\mathrm{mm}$ mesh size, and $4 \%$ Formalin for storage were used. All investigators collected three samples at each station and date. Unfortunately, we do not know how much grabs used during different periods of investigation differed regarding the penetration depth and the strength of shock wave.

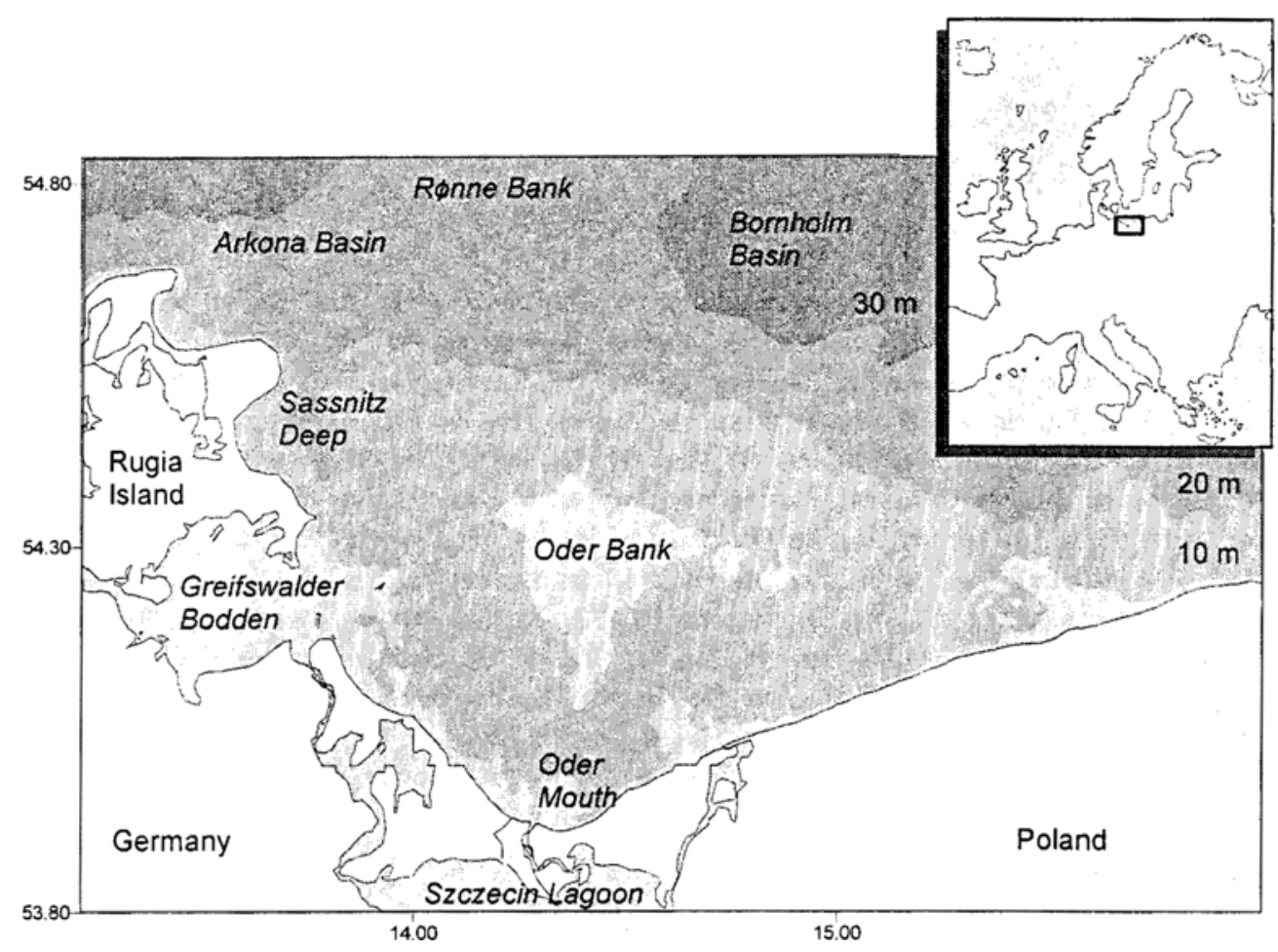

Fig. 1. Map of the area under investigation 
Table 1. Number of stations sampled in different habitat types of the Pomeranian Bay during three investigation periods

\begin{tabular}{|c|c|c|c|c|}
\hline \multirow[t]{2}{*}{ Depth } & \multirow[t]{2}{*}{ Ared } & \multicolumn{3}{|c|}{ Number of stations } \\
\hline & & Lowe (196.3) & $\begin{array}{l}\text { Gosselck (1985) } \\
\text { Warzocha (1995) }\end{array}$ & $\begin{array}{c}\text { Powilleit et al } \\
\text { (1995) }\end{array}$ \\
\hline $5-10 \mathrm{~m}$ & Oder Bank & 7 & 2 & 3 \\
\hline $10-15 \mathrm{~m}$ & near shore & 5 & 5 & 8 \\
\hline $10-20 \mathrm{~m}$ & off shore & 23 & 7 & 17 \\
\hline $20 \mathrm{ml}$ & Sassnitz Deep & 11 & - & 2 \\
\hline $20-30 \mathrm{~m}$ & Arkona Basin & 10 & 7 & 5 \\
\hline $20-30 \mathrm{~m}$ & Bornholm Basin & 2 & 2 & - \\
\hline
\end{tabular}

The data sets compared here are based on 58 stations sampled by Löwe (1963), 23 stations samp!ed by Cosselck (1985) and Warzochd (1995) and 35 stations sampled by Powilleit et al. (199.5). Although all three station grids covered the main habitat types of the study area, sampling sites differed between investigation periods (Table 1, Fig. 5). The border between Germany and Poland runs through the middle of the study area and. therefore, all investigations were restricted either to the German or Polish part of the bay.

Samples were mainly collected outside of the reproduction time in April/May and October/November. About $20 \%$ of the samples were taken in July/August. However. the influence of high spat densities on species abundances is almost negligible, because most of the juveniles pass through the meshes of the $1-\mathrm{mm}$ sieve (Powilleit et al., 1995).

The Pomeranian Bay harbours about 40 different macrofauna species (Kube et al., $1996)$ but abundances of only 14 species could be used for a cluster analysis. The patcniiy distributed biue mussel. Mytilus edulis, and all associated crustaceans were excluded from the cluster analysis because they cannot be sampled precisely with only three replicate grabs. Due to the patchy distribution of Mytilus-clumps, relative $95 \%$. confidence limits were greater than $100 \%$ of the mean values (Powilleit et al., 1995). We also had to exclude all small polychaetes and the mud snail Hydrobia ulvae from the cluster analysis because these species were not counted by Löwe (1963) and Warzocha 11995). Furthermore, three infaund species (Hediste diversicolor, Marenzelleria viridis, Mya arenaria), burying deeper than $5 \mathrm{~cm}$, were excluded from the cluster analysis.

However, the species that could be used for the cluster analysis are representatives of all major habitat types of the study area. i.e. the deeper parts along the slopes of the adjacent Arkond and Bornholm Basins, the exposed shallow sandy central parts, and the sheltered river mouth (Tiable 2).

Abundance data were also used to plot species distribution maps. The maps were computed by kriging (Cressie, 1991).

Biomass comparisons were restricted to the bivalves $M$. edulis, Macoma balthica, and $M$. arenaria. These species account for more than $90 \%$ of the total zoobenthic biomass (Kube et al., 1996). They are characterized by a longevity of more than ten years and a low $P / B$ ratio (Kube, 1996b).

Bivalve biomass data of Löwe (1963) and Powilleit et al. (1995) were recalculated by allometric shell length-ash free dry weight (AFDW) relationships for samples taken 


\begin{tabular}{|c|c|c|c|c|c|c|c|c|c|c|c|c|c|c|c|c|c|}
\hline & $\underline{\theta}$ & $\begin{array}{l}\Xi \\
\Xi \\
\Xi\end{array}$ & $\checkmark$ & $\theta$ & 0 & 0 & $\stackrel{\infty}{\sim}$ & 0 & 0 & $m$ & 0 & 0 & 0 & & & - & $\Rightarrow$ \\
\hline & & 8 & 8 & 0 & 0 & 0 & 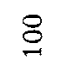 & 0 & 0 & $\ddot{m}$ & 0 & 0 & 0 & 0 & 0 & $\approx$ & \\
\hline & $=$ & $\stackrel{\overrightarrow{3}}{\overrightarrow{3}}$ & - & 0 & $\sigma$ & 0 & $\mathcal{N}$ & in & 0 & 0 & 0 & $\stackrel{\varphi}{\bullet}$ & 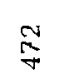 & 0 & $\stackrel{\infty}{*}$ & m & \\
\hline & $=$ & 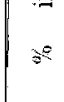 & \pm & 0 & $\hat{m}$ & 0 & 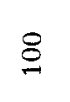 & $£$ & 0 & 0 & 0 & $\tilde{6}$ & 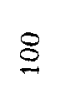 & $=$ & is & $\stackrel{8}{9}$ & - \\
\hline & $\overline{0}$ & $\stackrel{\stackrel{:}{\Xi}}{\dot{\vec{g}}}$ & gi & $n$ & 0 & $\stackrel{0}{-1}$ & $\frac{8}{7}$ & 4 & 0 & $\stackrel{\leftrightarrow}{\sim}$ & 0 & iี & $N$ & $\Xi$ & $\forall$ & $\stackrel{n}{\sim}$ & \\
\hline & 0 & 3 & $\vec{\infty}$ & 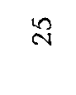 & $\stackrel{2}{2}$ & फि & $\stackrel{8}{g}$ & in & 0 & 88 & 0 & $\stackrel{\infty}{\infty}$ & 0 & $\vec{m}$ & $\stackrel{3}{3}$ & $\stackrel{\infty}{\infty}$ & \\
\hline & $\overline{0}$ & $\begin{array}{l}\stackrel{y}{\Xi} \\
\dot{\Xi}\end{array}$ & 0 & 0 & 0 & लू & $\stackrel{\mathscr{\sigma}}{\stackrel{్}{\sigma}}$ & - & 0 & $\vec{\pi}$ & 0 & - & 0 & 0 & - & $\Xi$ & $\Rightarrow$ \\
\hline & $\infty n$ & ? & 0 & 0 & 0 & $\mathscr{\infty}$ & 8 & \pm & 0 & $\stackrel{8}{2}$ & 0 & \pm & 0 & 0 & 0 & in & \\
\hline$\frac{\pi}{\frac{a}{\pi}}$ & $\stackrel{5}{=}$ & $\begin{array}{l}\vec{\Xi} \\
\dot{\Xi} \\
\dot{\Xi}\end{array}$ & 0 & 0 & 0 & ஜ & 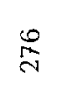 & 0 & - & $\overrightarrow{8}$ & 0 & $m$ & $\infty$ & 0 & $\sim$ & 0 & $\sigma_{2}$ \\
\hline $\begin{array}{l}\frac{\sigma}{0} \\
\stackrel{\vec{y}}{\Xi}\end{array}$ & $\bar{\sigma}$ & $\vdots ?$ & 0 & 0 & 0 & $\tilde{\sigma}$ & $\stackrel{8}{\circ}$ & 0 & $\stackrel{m}{\rightarrow}$ & $\mathscr{M}$ & 0 & $\stackrel{9}{\rightarrow}$ & $=$ & 0 & 9 & m & \\
\hline $\begin{array}{l}\Xi \\
\frac{\Xi}{\Xi} \\
\Xi\end{array}$ & $\widehat{\widehat{\underline{I}}}$ & $\begin{array}{l}\stackrel{\vec{E}}{\mathrm{E}} \\
\dot{\vec{g}}\end{array}$ & 0 & $\circ$ & 0 & $\stackrel{\infty}{\infty}$ & $\frac{m}{m}$ & 0 & 0 & & 0 & 0 & - & 0 & $\overbrace{\tilde{H}}$ & 0 & $\stackrel{\infty}{-}$ \\
\hline $\begin{array}{l}0 \\
G \\
\vec{s} \\
\underline{g}\end{array}$ & $\vec{m}$ & 3 & 0 & 0 & 0 & $\stackrel{8}{ }$ & 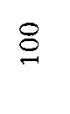 & $a$ & 0 & ले & 0 & 0 & in & 0 & 8 & 0 & \\
\hline $\overrightarrow{\bar{U}}$ & $\mathbb{\mathcal { J }}$ & $\begin{array}{l}\Xi \\
\dot{g}\end{array}$ & 0 & & 0 & ले & 㤐 & 0 & in & $\nexists \vec{N}$ & - & $\curvearrowright$ & - & 0 & 吕 & $\nabla$ & $\circ$ \\
\hline & $\ddot{m}$ & o & 0 & 0 & 0 & $\underset{\sim}{8}$ & $\nsubseteq$ & 0 & $\mathscr{N}$ & $\mathcal{B}$ & is & $\underset{\sim}{\vec{H}}$ & $\infty$ & 0 & $\mathbb{0}$ & 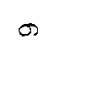 & \\
\hline & $\stackrel{\varrho}{\varrho}$ & $\begin{array}{l}\vec{B} \\
\dot{\vec{g}}\end{array}$ & 0 & 0 & 0 & $\infty$ & $\sqrt[5]{7}$ & 0 & is & $\underset{\sim}{\stackrel{N}{N}}$ & 0 & $N$ & 0 & 0 & in & 0 & $\bar{N}$ \\
\hline & $v$ & $3^{\circ}$ & 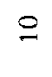 & 0 & 0 & 8 & 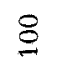 & 0 & 8 & $\stackrel{8}{9}$ & $\stackrel{-}{\circ}$ & $\stackrel{\circ}{\circ}$ & 0 & 0 & 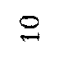 & 0 & \\
\hline & $\mathbb{\Xi}$ & 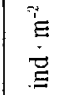 & $\frac{m}{2}$ & $\stackrel{N}{N}$ & 0 & 0 & $\frac{m}{2}$ & $\infty$ & 0 & $\approx$ & 0 & $\stackrel{\infty}{\stackrel{\sim}{\sharp}}$ & $\circ$ & ஓ & $\neg$ & in & $m$ \\
\hline & - & $3^{2}$ & $\stackrel{8}{\circ}$ & $\stackrel{\infty}{\infty}$ & 0 & m & $\underset{-}{\stackrel{8}{9}}$ & $\pi$ & 0 & 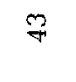 & 0 & $\underset{\sim}{\S}$ & 0 & $\S$ & & 8 & \\
\hline & & & 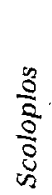 & 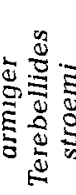 & $\begin{array}{l}\overline{0} \\
0 \\
0 \\
0 \\
0\end{array}$ & 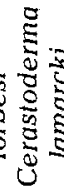 & : & : & 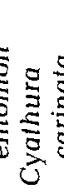 & 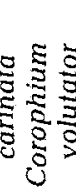 & 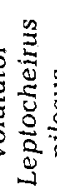 & $\frac{2}{0}$ & 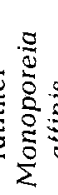 & 胥 & 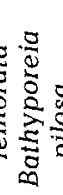 & 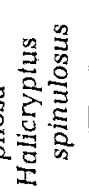 & 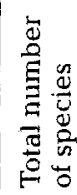 \\
\hline
\end{tabular}


in April 1993 (Kube, 1996b). Biomass data of Gosselck (1985) and Warzocha (1995) were excluded from the analysis, because they had not measured the shell length of bivalves.

As already mentioned, the patchily distributed, mobile Mytilus-clumps cannot be sampled precisely with less than 10 grab subsamples. The data set of Löwe (1963) provided enough parallel grab samples per cluster group to estimate biomass means. Biomass data from Powilleit et al. (1995) were validated by additional dredge samples and video observations (Kube, 1996b).

Biomass values of $M$. arenaria obtained from Van Veen grab samples represent only about $70 \%$ the standing stock (Powilleit et al., 1995).

\section{LONG-TERM VARIABILITY OF ENVIRONMENTAL FACTORS}

\section{Oceanography}

The water column in the Pomeranian Bay is usually well mixed down to a depth of about $15 \mathrm{~m}$ by wind forcing. As a consequence, fresh water supplied by river runoff affects the entire water column (Trzosinska \& Cyberska, 1992). There is a strong nega-

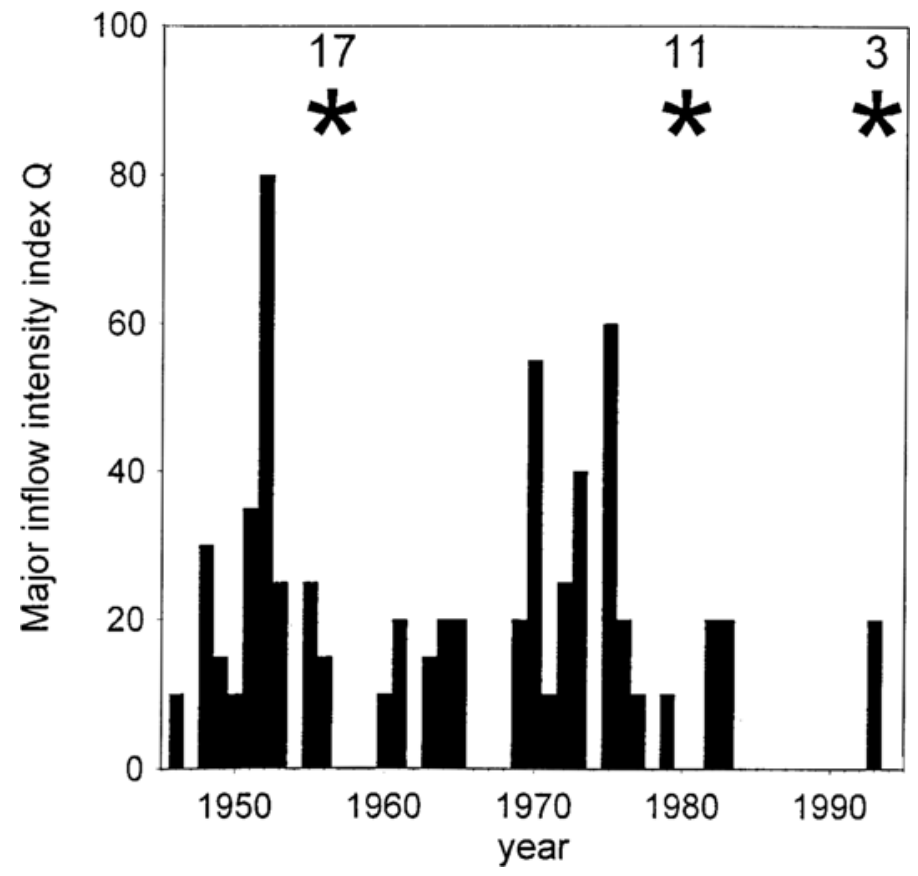

Fig. 2. Intensity index of inflows of highly saline water into the Baltic Sea (annual maximum) between 1946 and 1993 (redrawn from Franck \& Matthäus, 1992, see Matthäus \& Franck, 1992 for calculation of the index). Asterisks indicate benthos investigations. Values above the asterisks give the total number of major inflow events for the ten year periods preceding each benthos investigation 
tive relationship between runoff data of the Oder River and annual salinity means (1950-1992, $\mathrm{r}=-0.7, \mathrm{p}<0.0 .5, \mathrm{n}=41$ ).

Annual salinity means showed no trend within the last 40 years. Values fluctuated between $6-8 \%$ near the mouth of the Oder and 7-9\% on its banks (Nehring, 1990; Cyberski, 1992).

A strong vertical salinity gradient occurs at the steep northern edges of the bay. The $10 \%$ halocline is known to fluctuate there between $15-35 \mathrm{~m}$ depth near the Arkona Basin and 40-60 $\mathrm{m}$ depth near the Bornholm Basin. Changes in halocline depth depend mainly on the frequency and intensity of the inflow of highly saline water from the Kattegat into the Baltic Sea (Nehring et al., 1994; Matthäus \& Lass, 1995). Occasionally, upwelling-like events are responsible for an uprising of the halocline. As a result, deep water from the Arkona Basin propagates into the bay via the Sassnitz Deep. Such upwelling events sometimes cause strong stratification in the western part of the Pomeranian Bay at depths between 10 and $15 \mathrm{~m}$ (Lass, pers. comm.)

The oxygen of the highly saline deep water, inflowing from the North Sea during the winter, is depleted during periods of stagnation. Hence, the oxygen concentration of the deep water below the halocline depends on both, on biological activity and on the frequency and intensity of major inflows. Until the 1970s, major inflows were observed more or less regularly (Fig. 2). Seventeen major inflow events were observed within a period of ten years preceding the investigations of Löwe (1963), and eleven inflows occurred within the ten years before the studies carried out by Gosselck (1985) and Warzocha (1995). A long lasting stagnation period since 1983 resulted in extreme decreases of oxygen concentrations in the Bornholm Basin and, during summer, even in the Arkona Basin (Franck \& Matthäus, 1992; Nehring et al., 1994). This stagnation period was interrupted in January 1993 (Matthäus \& Lass, 1995)

\section{Temperature}

Fluctuations of annual means of water temperature in the Pomeranian Bay are strongly related to the severity of the preceding winter season (Cyberska, 1992). Although the overall trend of the severeness index of winter seasons is negative $(1946-1993, r=-0.21, p>0.05, n=49)$, means of severeness indices of a period of ten winter seasons before the beginning of the investigation did not differed (Fig. 3). Differences occurred in the course of the severeness index over the three ten year periods. Whereas the investigations of Löwe (1963), Gosselck (1985), and Warzocha (1995) followed a period of cold winters preceded by a period of mild winters, opposite conditions predated the investigation of Powilleit et al. (1995).

\section{Food supply}

The nitrogen input of the Oder River increased from 10000-20000 $\mathrm{t} \cdot \mathrm{a}^{-1}$ in the 1960 s to $70000-80000 \mathrm{t} \cdot \mathrm{a}^{-i}$ in the 1990) (Cyberska et al., 1992, 1993; Lampe, 1993). Surface chlorophyll a concentrations have doubled in the whole study area between 1970 and 1990 (Schulz \& Kaiser, 1986; Nakonieczny et al., 1991; Renk, 1992). The increase in phytoplankton biomass resulted in a decreasing water transparency and a heavy loss of macrophytobenthos in the adjacent Greifswalder Bodden (Messner \& Von Oertzen, 1991). 


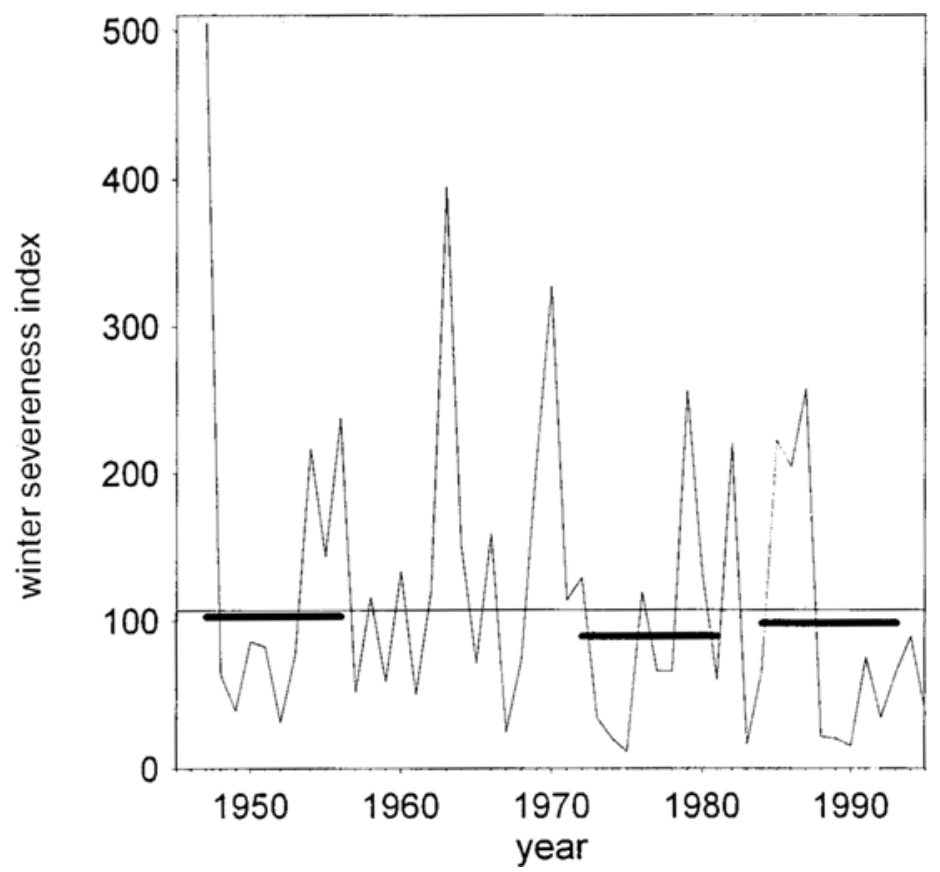

Ficf. 3. Index of the severity of the winter seasons between $1946 / 47$ and $1994 / 95$ (sum of minus degrees (daily means) per winter season, data from the Meteorological Station Warnemünde, F.R.C.). Thin horizontal line shows the long-term average. Thick horizontal lines show the average for the ten-year periods preceding each benthos investigation

Furthermore, an increasing accumulation of organic matter was observed in sediments of the sheltered Greifswalder Bodden and in the Sassnitz Deep (Lampe, 1993; Leipe et al., 1995; Nausch, pers. comm.). However, no accumulation of organic matter was found for sandy sediments of the Pomeranian Bay above the $15 \mathrm{~m}$ isobath (Neumann \& Bublitz, 1969; Koine, 1995).

\section{RESULTS}

\section{Long-term changes of the macrozoobenthos assemblages}

Eight groups of stations were separated by cluster analysis at a $45 \%$ similarity threshold and were computed to spatial distribution maps for all three investigation periods (Figs 4 and 5). The first group combines stations with a high species richness in the southern Arkona Basin. The second group covers shallow coastal locations near the Oder Mouth and near the Greifswalder Bodden. Group three is separated into two main sub-groups $3 a$ and $3 b$, representing exposed sandy stations on the shallow Oder Bank and its deeper surroundings, respectively. The fourth group contains deeper sites in the southeast of the bay, which are characterised by low densities of characteristic 


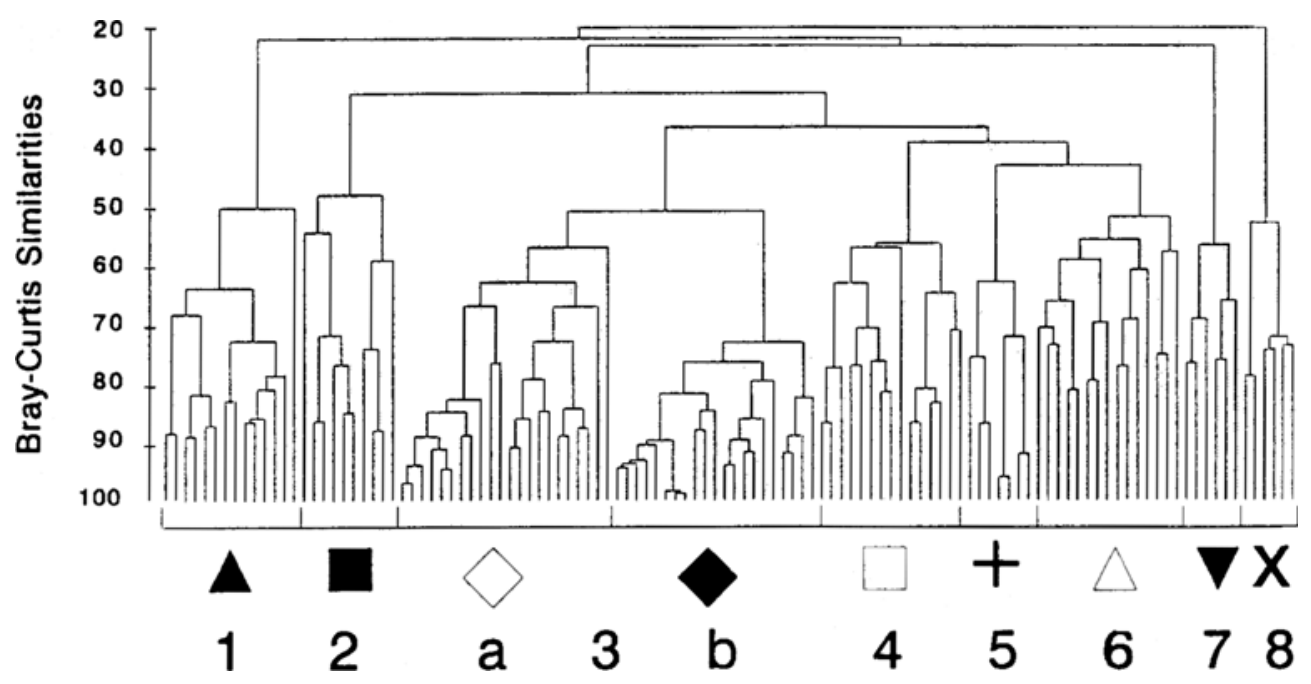

Fig. 4 Dendrograin of the 116 stations using group)-average clustering from Bray-Curtis similarities on square root-transtormed abundances (presence $>1 \%$ ). The eight groups of stations separated at a $45^{\prime \prime \prime}$ threshold are indicated (symbols and numbers). Additionally, the third station group was divided into the sub-groups $3 \mathrm{~d}$ and $3 \mathrm{~b}$ )

species of the sand bottom community (Bathyporeia pilosa, Cerastoderma lamarcki). Group six represents stations in the Sassnitz Deep with a high species richness. Group seven includes stations in the deeper northern part at the slope to the Bornholm Basin. This station group lacks several species typical for the western Baltic Sea. Groups five and eight show a heavily reduced species richness (Table 2).

The spatial distribution maps (Fig. 5) show changes in the areal extension of cluster groups from one investigation period to the next, especially in the western half of the bay. Cluster group one and six, representing diverse macrofauna assemblages in the southern Arkona Basin and in the Sassnitz Decp, almost disappeared between 1957 and 1993. The Oder Bank cluster group (3a) covered the largest part of the Pomeranian Bay in the 1950s. Since 1981 its extension has been restricted to the shallow central parts of the Oder Bank. The deeper sandy areas are now part of the cluster group $3 \mathrm{~b}$. Today, a wide range is also covered by cluster group four, as compared with the 1950s when it was restricted to deeper parts in the West near the Isle of Rugia in the 1950s. The cluster groups five and eight represent stations, more than $15 \mathrm{~m}$ deep, sampled in 1981 and 1993 in the Sassnitz Deep and along the former Oder River bed. These assemblages were absent during the investigation period of Löwe (1963).

\section{Changes in individual species}

Distribution pattern of several species under investigation have changed between 1958 and 1993. The crustaceans Monoporeia affinis and Pontoporeia femorata vanished entirely since 1981 (Fig. 6). Only a few single individuals of the isopod Saduria 

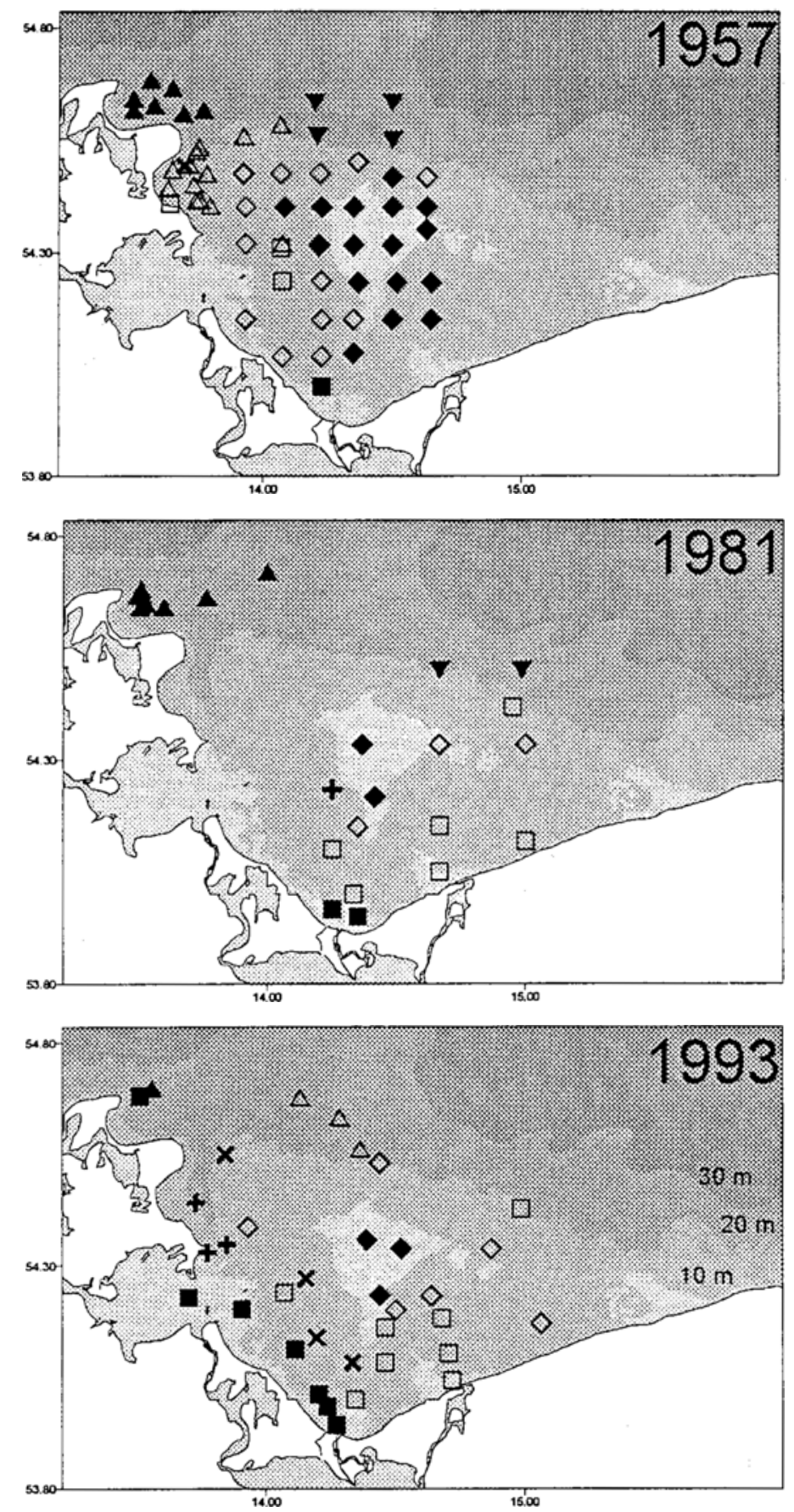

Fig. 5. Maps showing the spatial pattern of different cluster groups during the investigation periods of Löwe (1963). Gosselck (1985), Warzocha (1995), and Powilleit et al. (1995). Symbols are the same as in Fig. 4. See text for further explanations 


\section{Monoporeia affinis}
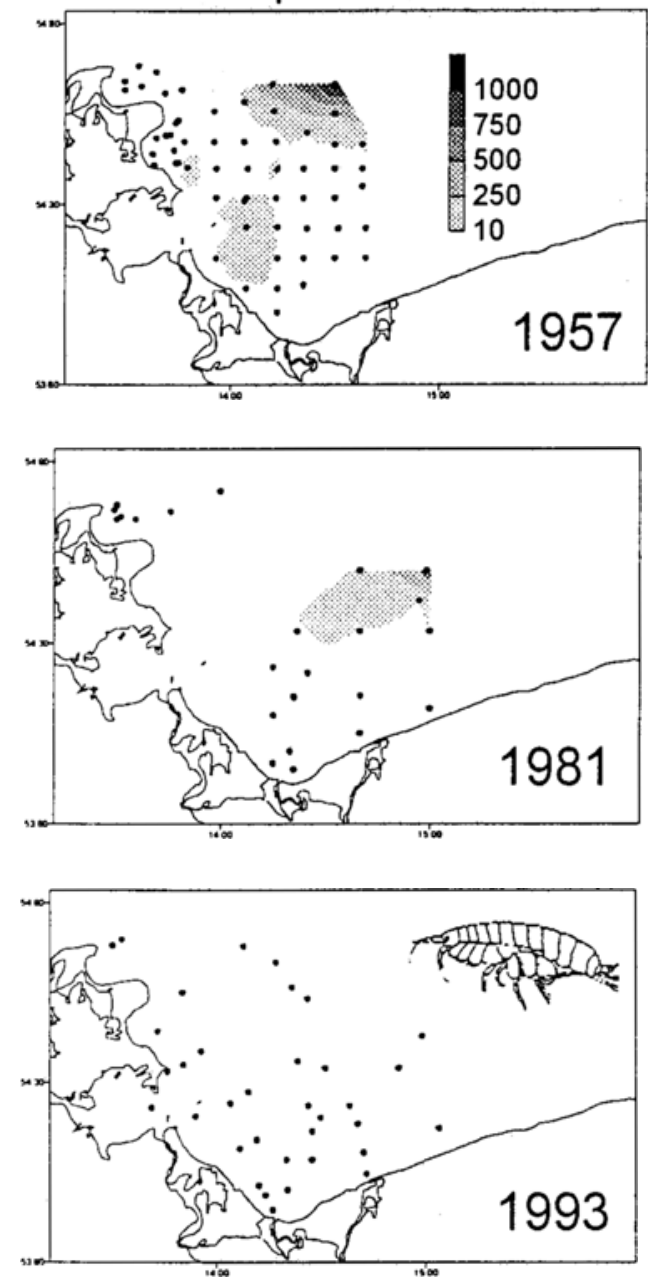

Pontoporeia femorata
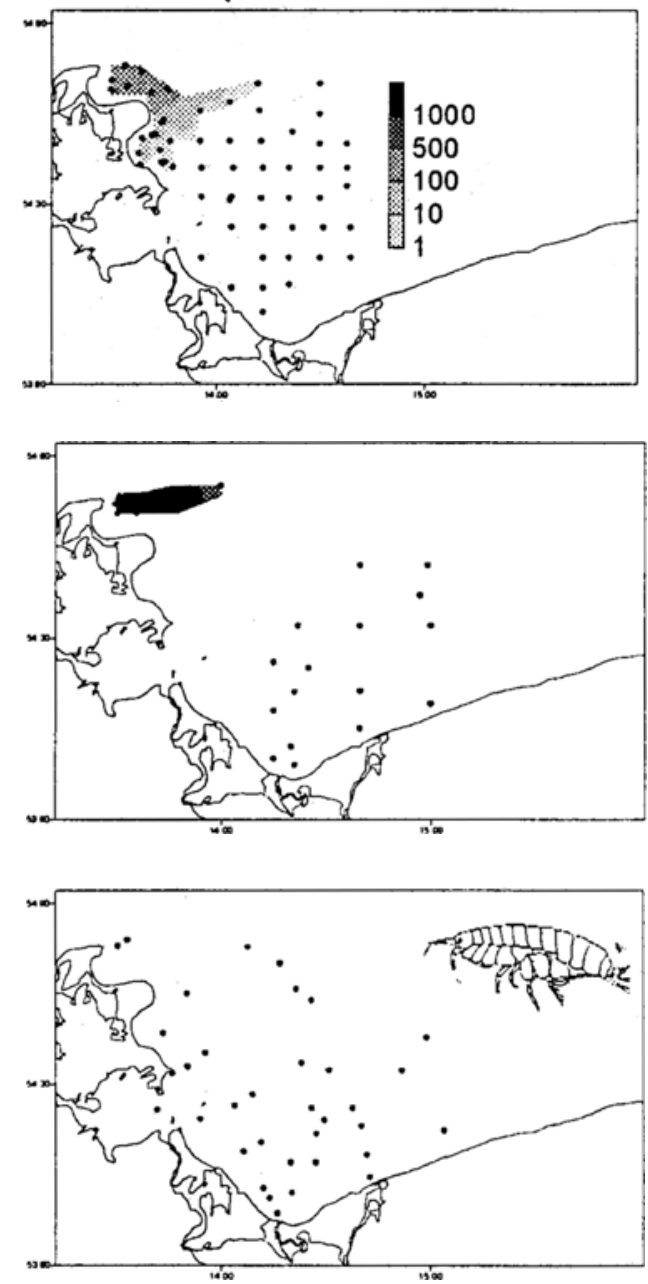

Fig. 6. Distribution of Monoporeia aiinis and Pontoporeia femorata (ind. $m$-) during the investigation periods of Löwe (1963), Gosselck (1985), Warzocha (1995), and Powilleit et al. (1995)

entomon were found since 1993. All other species, that were abundant in the southern part of the Arkona Basin and in the Sassnitz Deep between 1955 and 1980 were discovered to be very scarce in 1993. The cockle C. lamarcki and the amphipod B. pilosa almost disappeared from the southwest of the study area. Their densities remained stable only on the Oder Bank (Fig. 7). Densities of the amphipod Corophium volutator have probably increased near the Oder Mouth. No changes were observed for the isopod Cyathura carinata and the amphipod Leptocheirus pilosus (Fig. 8). 
Bathyporeia pilosa
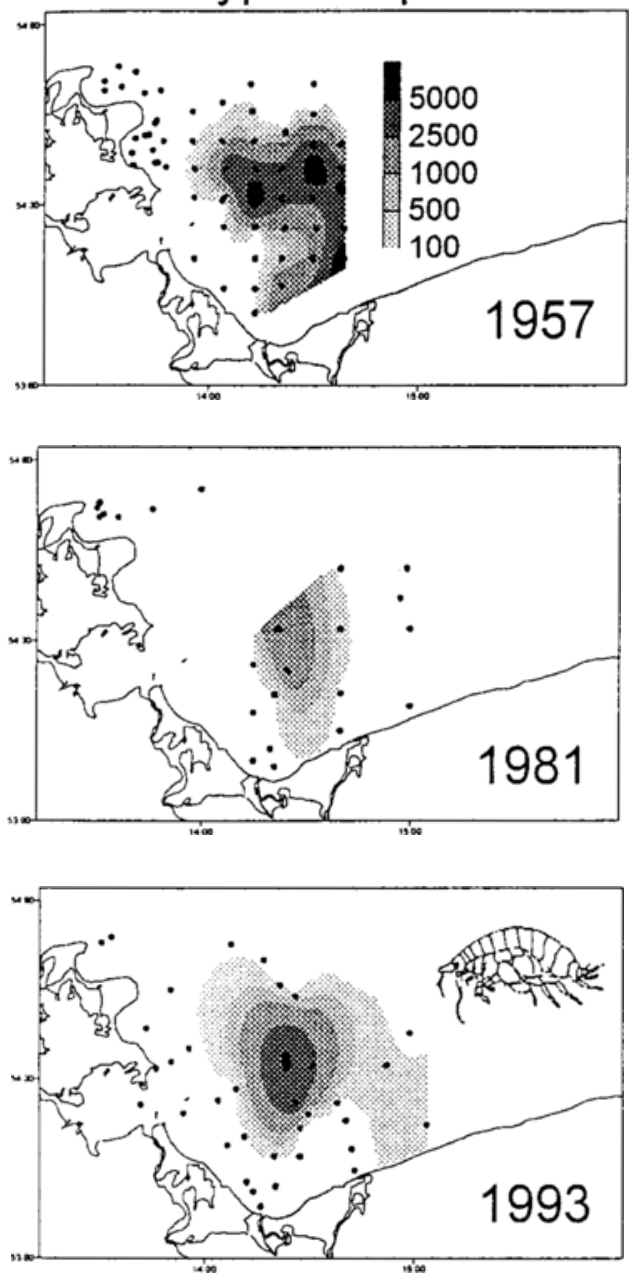

Cerastoderma lamarcki
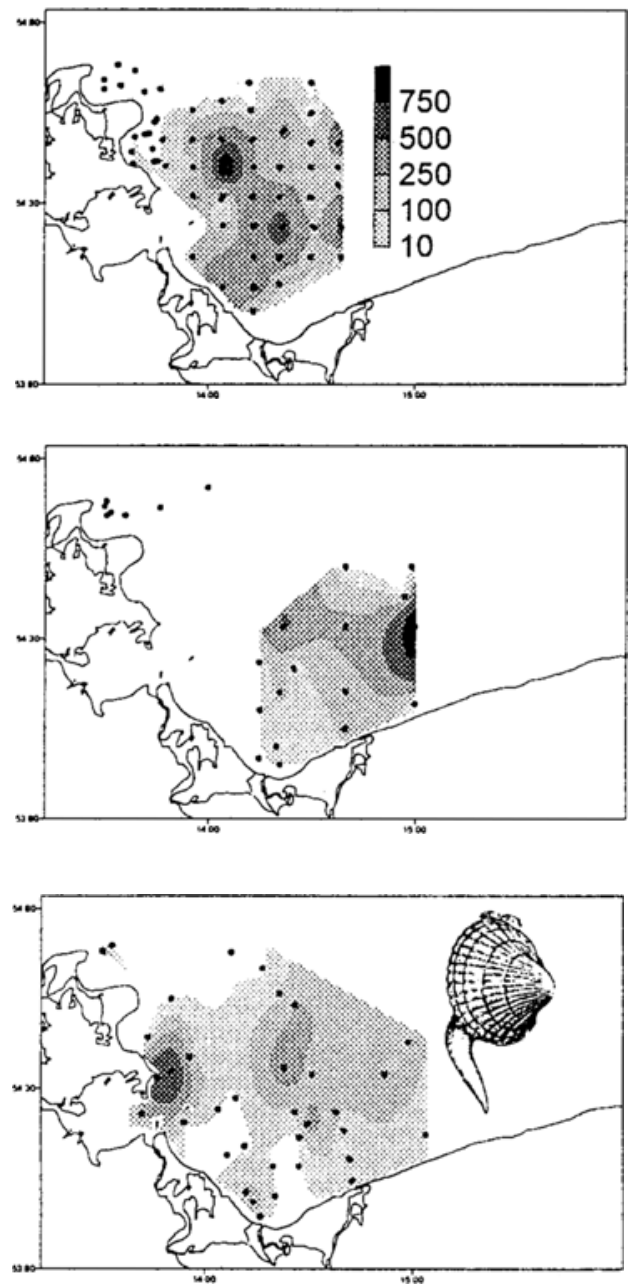

Fig. 7 Distribution of Cerastoderma lamarcki and Bathyporeia pilosa (ind. $m$ ") during the investigation periods of Löwe (1963). Gosselck (1985), Warzocha (1995), and Powilleit et al. (1995)

\section{Macrozoobenthic biomass}

Changes in the biomass distribution pattern between the 1950s and 1990s are shown for three bivalve species in Fig. 9. The distribution pattern of $M$. edulis and $M$. arenaria have not changed within the past 35 years. The biomass distribution pattern of $M$. balthica in 1993 looked almost like an inversed picture of its 1950s distribution. Biomass values of $M$. balthica have decreased in the southwest and increased north of the Oder Bank. 


\section{Corophium volutator}
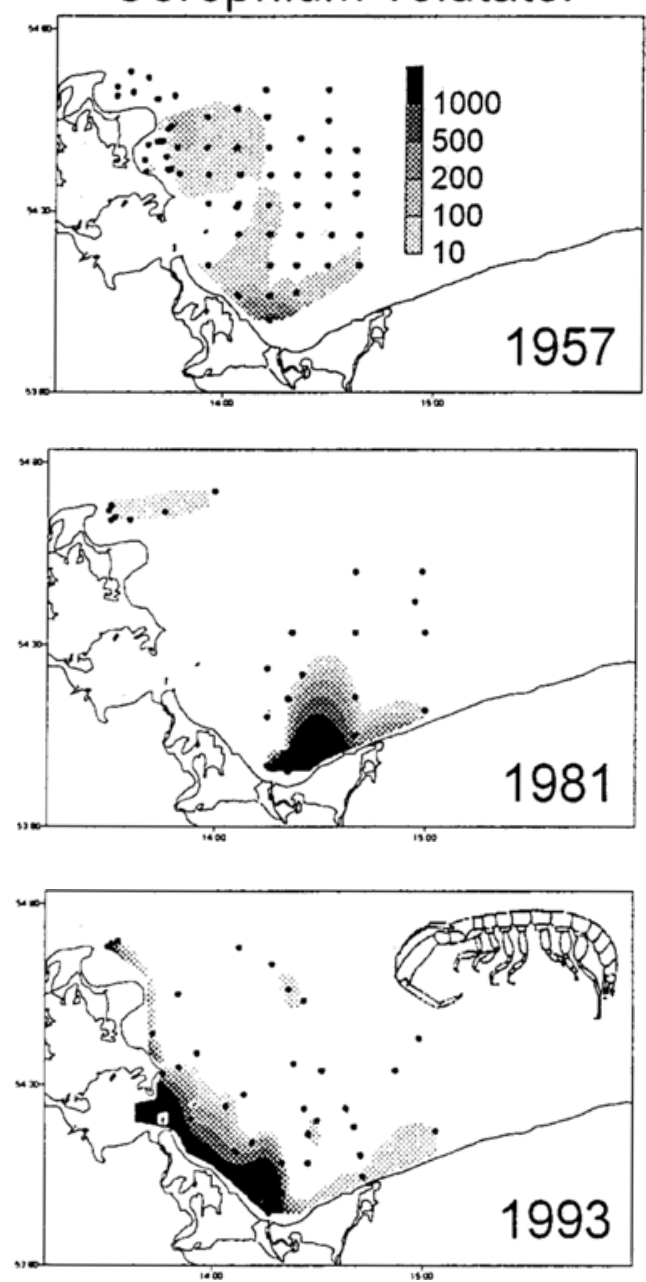

Cyathura carinata
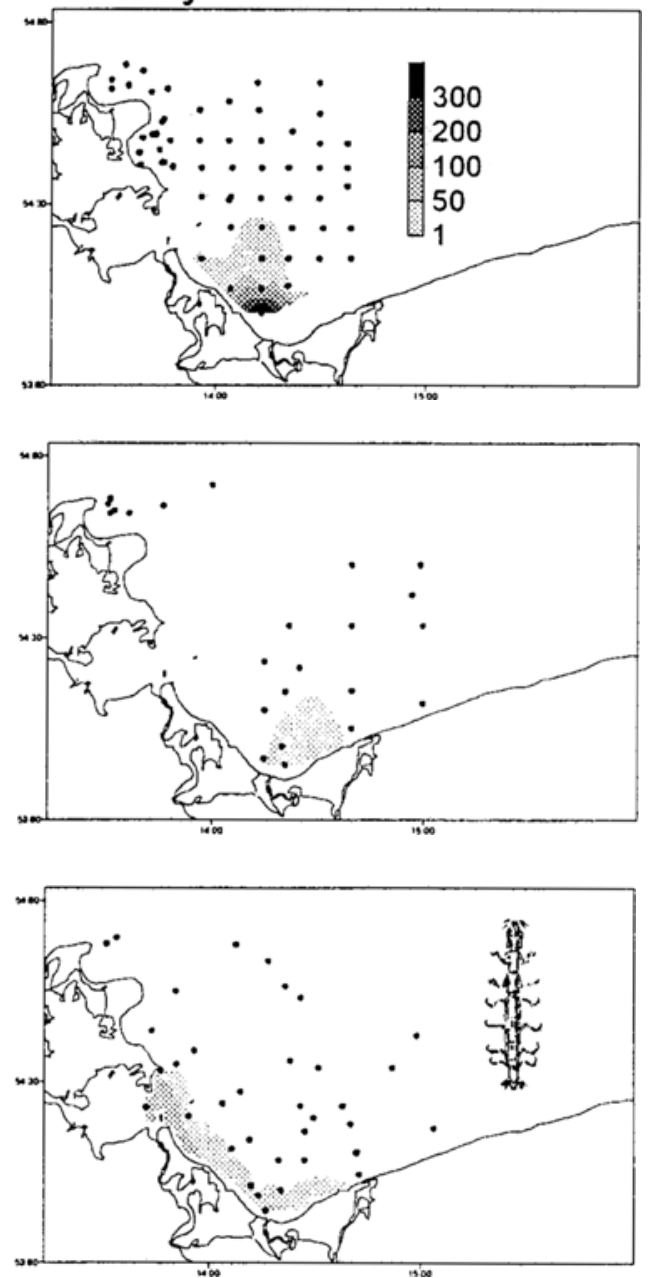

Fig. 8. Distrubution of Corophium volututor and Cyathura carinuta (ind. $\cdot \mathrm{m}^{2}$ ) during the investugation periods of Lowe (1963), Gosselck (1985), Warzocha (1995), and Powilleit et al. (1995)

The mean biomass of $M$. edulis and $M$. arenaria was about eight times higher in 1993 than in the 1950s. The increase is strongly significant. Mean biomass values of $M$. balthica showed no difference between the two investigation periods (Table 3 ).

To obtain a more detailed view, quantitative changes in bivalve biomasses were also calculated separately for cluster groups 3a, 3b, 4 and 6 (Table 3). Large differences occurred between the cluster groups. Whereas the biomass of $M$. edulis strongly increased in the southwest, biomass values did not increase on the Oder 


\section{Mytilus edulis}
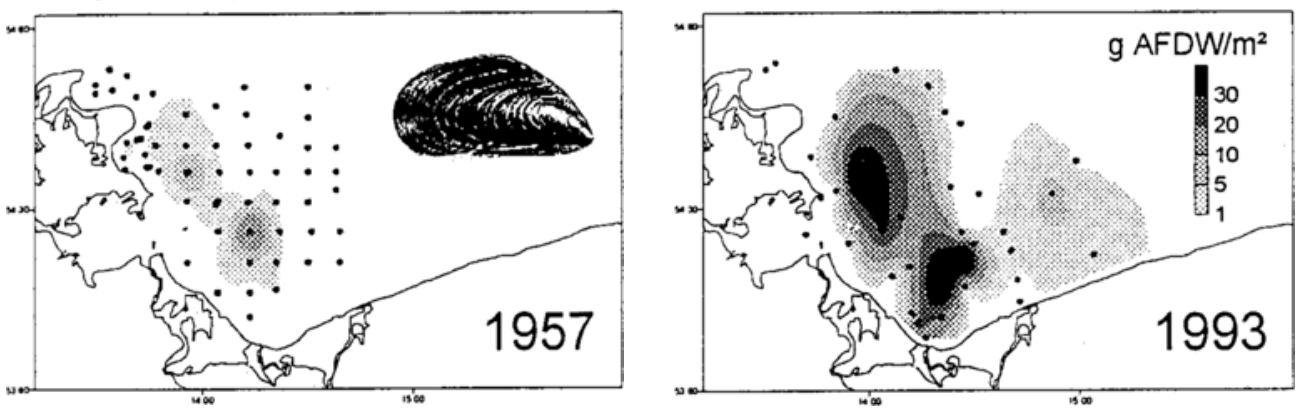

\section{Macoma balthica}
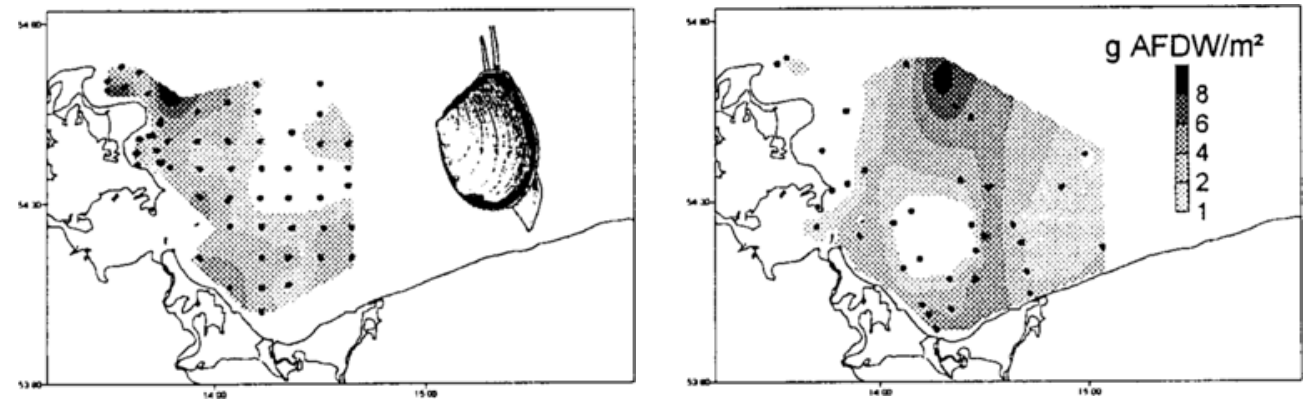

\section{Mya arenaria}
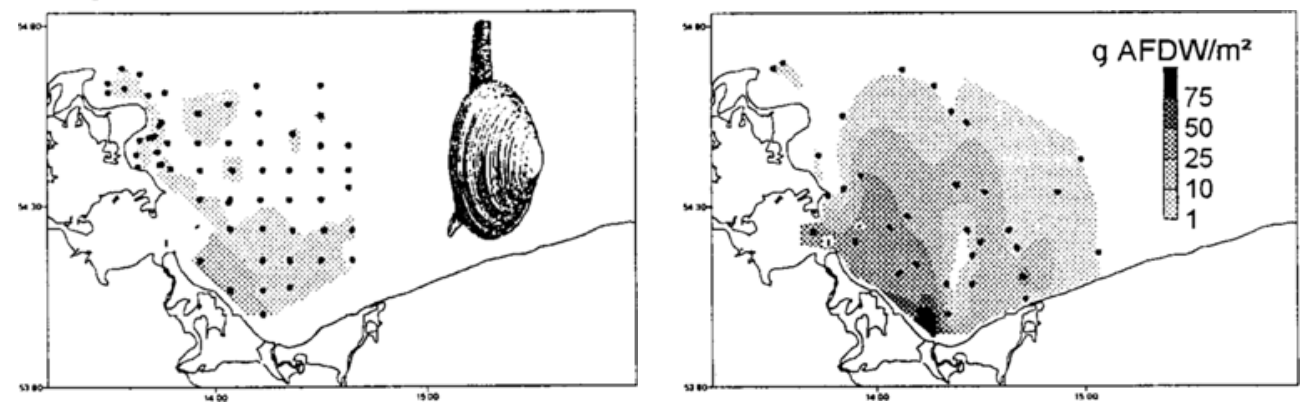

Fig. 9. Biomass distribution of Mytilus edulis, Macoma balthica and Mya arenaria (g AFDW $\left.\cdot \mathrm{m}^{-2}\right)$ during the investigation periods of Löwe (1963) and Powilleit et al. (1995)

Bank. The biomass of $M$. arenaria increased in all cluster groups, except for decrease in cluster group 6. However, in all cases sample sizes were too small to obtain significant results 
Table 3. Changes in the biomass values (g AFDW $\cdot \mathrm{m}^{2}$ ) of Mytilus edulis (Me), Macoma balthica (Mb) and Mya arenaria (Ma) in the Pomeranian Bay. Asterisks denote statistical significant changes $(\cdots p<0.001$, Mann-Whitney U-test)

\begin{tabular}{|c|c|c|c|c|c|c|}
\hline \multirow[t]{2}{*}{$\begin{array}{l}\text { Cluster group } \\
\text { (n 1955-58/n 1993) }\end{array}$} & \multirow[t]{2}{*}{ Species } & \multicolumn{2}{|c|}{$\begin{array}{c}1955-58 \\
\text { (Löwe, 1963) }\end{array}$} & \multicolumn{2}{|c|}{$\begin{array}{c}1993 \\
\text { (Powilleit et al., 1995) }\end{array}$} & \multirow{2}{*}{$\begin{array}{c}\text { Factor of } \\
\text { changes } \\
\text { in the } \\
\text { mean }\end{array}$} \\
\hline & & mean \pm se & median & mean \pm se & median & \\
\hline \multirow{3}{*}{$\begin{array}{l}3 \ddot{a} \\
(13 / 6)\end{array}$} & Me & $3.4 \pm 1.9$ & 0.4 & $11.5 \pm 7.3$ & 5.32 & 3.4 \\
\hline & $\mathrm{Mb}$ & $2.5 \pm 0.4$ & 2.2 & $3.1 \pm 0.9$ & 2.1 & 1.2 \\
\hline & Ma & $5.4 \pm 2.5$ & 1.1 & $12.6 \pm 4.2$ & 8.9 & 2.3 \\
\hline \multirow{3}{*}{$\begin{array}{l}3 b \\
(16 / 3)\end{array}$} & $\mathrm{Me}$ & $0.3 \pm 0.1$ & 0.2 & $0.3 \pm 0.2$ & 0.1 & 0.8 \\
\hline & $\mathrm{Mb}$ & $1.2 \pm 0.2$ & 1.1 & $2.5 \pm 1.5$ & 2.3 & 2.0 \\
\hline & Mar & $1.1 \pm 0.2$ & 1.0 & $9.7 \pm 4.6$ & 12.7 & 9.0 \\
\hline \multirow{3}{*}{$\begin{array}{l}4 \\
(3 / 8)\end{array}$} & $M e^{2}$ & $1.9 \pm 1.7$ & 0.3 & $14.5 \pm 8.1$ & 2.0 & 7.8 \\
\hline & Mb & $1.4 \pm 0.6$ & 1.8 & $2.2 \pm 0.6$ & 1.9 & 1.6 \\
\hline & Md & $0.4 \pm 0.2$ & 0.4 & $13.6 \pm 6.4$ & 5.0 & 34.6 \\
\hline 6 & $\mathrm{Me}$ & $0.8 \pm 0.4$ & 0.0 & $2.1 \pm 1.2$ & 2.1 & 2.6 \\
\hline \multirow[t]{2}{*}{$(13 / 3)$} & $\mathrm{Mb}$ & $3.6 \pm 0.5$ & 4.0 & $6.1 \pm 2.0$ & 6.9 & 1.7 \\
\hline & $\mathrm{Ma}$ & $2.4 \pm 1.0$ & 0.6 & $0.5 \pm 0.2$ & 0.4 & 0.2 \\
\hline \multirow{3}{*}{$\begin{array}{l}\text { all samples } \\
(58 / 3,3)\end{array}$} & $\mathrm{Me}$ & $1.1 \pm 0.5$ & 0.2 & $9.7 \pm 2.9$ & 2.0 & $8.5 \cdots$ \\
\hline & $\mathrm{Mb}$ & $2.5 \pm 0.3$ & 2.1 & $2.6 \pm 0.4$ & 2.3 & 1.0 \\
\hline & $\mathrm{Ma}$ & $2.4 \pm 0.7$ & 1.0 & $19.7 \pm 5.0$ & 8.6 & $8.1 \cdots$ \\
\hline
\end{tabular}

\section{DISCUSSION}

Reliability of data

Comparing datd that were gathered by different sampling methods is a general problem in evaluating past and present distribution patterns in the benthos (Reise et al., 1989). Unfortunately, iong-term data series are often lacking for sublittordl marine areas, due to the enomous costs of shipboard sampling. As a consequence, almost all documentations of long-term changes in the macrofauna of the Baltic Sed are based on reinvestigations of areas that had been studied intensively several decades ago (Rosenberg \& Moller, 1979; Cederwall \& Elmgren, 1980; Brey, 1986j.

For shallow waters in the western and southern Baltic Sea, we consider it unimportant to resample exactly the same sites in the same season, because:

1. Repositioning the research vessel on exactly the same station that had been sampled decades ago is impossible. Our own examinations of the precision of the navigation system which was used in the 1950 ) revealed a maximum error of $\pm 2 \mathrm{~km}$ for off shore areas without visible landmarks.

2. Often, there are no great differences in species composition in sandy areas, due to a very low species richness (Kube, 1992; Kube, 1996b; this study).

3. Density variations cannot be related to seasonal oscillations, provided by reproductive cycles. They are super-imposed by stochastic variations in hydrographic conditions (Arntz \& Rumohr, 1986; Brey, 1986; Kube, 1992).

4. Abrasion of sediment and bedload transport induced by local winds often cause changes in large-scale patchiness which cannot be covered by taking three parallel grab samples at a single station (Kube, 1996a). 
5. The sampling season has no strong effect on estimates of biomass values calculated from standardized length-weight relationships of bivalves with a high longevity and low $\mathrm{P} / \mathrm{B}$ ratio.

Hence, it seems to us that the coverage of all important habitat types and a large number of samples is more important for a statistical evaluation than spatial and seasonal accuracy. The total number of samples used in this study was much higher than the sample sizes of the investigations of Cederwall \& Elmgren (1980) and Brey (1986).

\section{Responses to eutrophication, and fluctuations in hydrography and climate}

Eutrophication is usually defined as a complex of phenomena triggered by an increase of limiting nutrients, which leads to increases in benthic abundance, biomass, and number of species but also to anoxic conditions in sediments and massive die-off of benthic animals (Pearson \& Rosenberg, 1978; Heip, 1995). Effects of eutrophication are difficult to measure and difficult to explain in a straightforward manner, because benthic communities usually respond in two ways; functionally by increasing their productivity, and structurally by adapting their composition to the higher food supply (Beukema, 1991).

In the Baltic Sea, rates of increase in bivalve biomass above the halocline varied between 5 and $47^{\prime \prime}$ of the initial values per year (Table 4). We observed an annual rate of increase of about $20 \%$ of the values estimated in the $1950 \mathrm{~s}$ which corresponds well to the rates of increase in nitrogen input. However, large differences occurred between individual species. The biomasses of the filter-feeders $M$ edulis and $M$. arenaria increased by almost $25 \%$ annually. No increase was found for C. lamarcki and $M$. balthica, the biomass dominants of the benthic communities in the 1950s. These findings are in accordance with the results reported by Cederwall \& Elmgren (1980), who also described that $M$. balthica was replaced by $M$. edulis as the dominant species. The change in dominances seems to be related to a larger complex of causes; competition for food and space, mechanical disturbance by drifting mussel clumps, and shifts in the redox potential in summer due to organic loading.

Table 4. Long-term increase in the biomass of molluscs in shallow sublittoral waters of the Baltic Sea. Initial biomass: biomass at the begin of the investigation period, later biomass: biomass at the end of the investigation period (' data from Cederwall \& Elmgren, 1980; investigations 1920-23 and 1976/77 around the islands of Öland and Gotland, ${ }^{2}$ data from Brey, 1986; investigations 1961-65 and 1982-83 in Kiel Bay, and ${ }^{3}$ this study)

\begin{tabular}{|lcccc|}
\hline Species & $\begin{array}{c}\text { Initial biomass } \\
\text { (g AFDW } \cdot \mathrm{m}^{-2} \text { ) }\end{array}$ & $\begin{array}{c}\text { Later biomass } \\
\text { (g AFDW } \cdot \mathrm{m}^{-2} \text { ) }\end{array}$ & $\begin{array}{c}\text { Mean increase } \\
\text { (g AFDW } \cdot \mathrm{m}^{-2} \text { ) }\end{array}$ & $\begin{array}{c}\text { Increase rate } \\
\left(\% / \mathrm{a}^{-1} \text { of the }\right. \\
\text { initial biomass) }\end{array}$ \\
\hline Mytilus edulis $^{1}$ & 0.09 & 2.3 & 0.04 & 46.5 \\
Cerastoderma spp. $^{1}$ & 0.03 & 0.14 & 0.002 & 8.5 \\
Macoma balthica $^{1}$ & 0.61 & 1.96 & 0.025 & 4.1 \\
Mya arenaria $^{1}$ & 0.003 & 0.05 & 0.001 & 30.3 \\
all Mollusca $^{2}$ & 2.1 & 12.8 & 0.54 & 25.5 \\
Mytilus edulis $^{3}$ & 0.2 & 2.0 & 0.05 & 25 \\
Macoma balthica $^{3}$ & 2.1 & 2.3 & 0.006 & 0.3 \\
Mya arenaria $^{2}$ & 1.0 & 8.6 & 0.22 & 22 \\
\hline
\end{tabular}


Spatial variations in the biomass increase of $M$. edulis demonstrate how strong limitations by other ecological factors can be. In the Pomeranian Bay, motile Mytilusclumps lay attached to Mya-shells on the sea floor. Depending on the current situation, single clumps can aggregate to patches of several square meters or disperse. Permanent erosion and strong bedload transports on the shallow Oder Bank prevent a successful settlement of mussel spat and encourage an accumulation of mussel-clumps in the deeper southwest of the bay. As a consequence, distribution patterns of $M$. edulis have not changed considerably during the past 35 years.

Below $15 \mathrm{~m}$, all stations showed a decrease in species richness in the 1990s. These changes were caused by an increase in oxygen depletion events in the Arkona Basin since 1983 and upwelling of deep water with lowered oxygen saturation from the Arkona Basin into the Pomeranian Bay via the Sassnitz Deep. Gosselck (1985) described a rate of increase in macrobenthic biomass of $16 \% \cdot \mathrm{a}^{-1}$ between the $1950 \mathrm{~s}$ and $1980 \mathrm{~s}$. M. balthica dominated macrobenthic biomass in 1980. Its biomass had increased annually by $53 \%$ of the initial value. First signs of macrofauna death in the Arkona Basin were noticed in 1984 (HELCOM, 1990). A change in the M. balthica population from larger to smaller individuals was observed and its biomass decreased. The total number of species decreased from 40 to 20 between 1980 and 1986 . The reduction in the numbers of the crustaceans $P$. femorata and Diastylis rathkei was particularly striking.

Changes in the species composition of the macrofauna of the Pomeranian Bay does not result in an increasing proportion of deposit-feeders, as reported previously by other investigators (Heip, 1995). Our analyses rather suggest an increase in the portion of filter-feeders until 1993. A high rate of resuspension of phytoplankton and particulate organic matter in the shallow parts of the bay might be the cause for these findings. This hypothesis is supported by the fact that no organic matter was accumulated in the sediments.

Besides eutrophication, some of the observed phenomena seem also to be triggered by variations in oceanographic and climatic conditions. Although changes due to eutrophication in the benthic communities of the Baltic Sea become more and more obvious, we are still unable to quantify the observed effects.

Events of oxygen depletion were found to increase in the southern Baltic Sea since the 1980s (Weigelt, 1991; Franck \& Matthäus, 1992). The large gap of important inflow events since 1983 might have been an important cause for the observed drastic changes in the oxygen regime of the Arkona Basin. Otherwise, the increase in benthic biomass until the 1980s might have accelerated the speed of oxygen depletion below the pycnocline during summer stratification.

Bivalves, the biomass dominants, show highly successful recruitment during summers following a cold winter (Beukema, 1982; Kube, 1996a). This positive effect can establish extraordinarily high biomasses after a series of severe winters due to the long life span of bivalves and, therefore, accelerates the speed of biomass increase (Beukema, 1989). Indeed, the population structure of $M$. arenaria differed strongly between the 1950 s and the 1990 s. Whereas smaller size classes prevailed during the late 1950s, the population was dominated by large specimens in 1993 (Kube, 1996a). This observation agrees with differences in the time course of the winter severeness index during the ten-year periods preceding both investigations. 
Acknowledgements. This is publication No. 262 of the Institut für Ostseeforschung Warnemunde, Germany. This study was supported by the Federal Ministry of Research and Technology (BMBF) under grant number $03 \mathrm{~F} 0105 \mathrm{~B}$

\section{LITERATURE CITED}

Andersin, A.-B., Lassig, J., Parkkonen, L. \& Sandler, H., 1978. The decline of macrofauna in the deeper parts of the Baltic proper and the Gulf of Finland. - Kieler Meeresforsch. (Sonderh.) 4. $23-52$.

Arntz, W. E. \& Rumohr, H., 1986. Fluctuations of benthic macrofauna during succession and in established community. - Meeresforsch. 31,97-114.

Beukema, J. J., 1982. Annual variation in reproductive success and biomass of the major macrozoobenthic species living in a tidal flat area of the Wadden Sea. - Neth. J. Sed Res. 16, $37 \ldots 45$.

Beukema, J. J., 1989. Long-term shanges in macrozoohenthic abundance on the tidal flats of the western part of the Dutch Wadden Sea. - Helgoländer Mecreslinters. 43, 405-4:5.

Beukema, J. J., 1991. Changes in composition of bottom fauna of a tidal-flat area during a period of eutrophication. - Mar. Biol. 111, 293-301

Brey, T., 1986. Increase in macrozoobenthos above the halocline in Kiel Bay comparing the 1960 s with the 1980s. - Mar. Ecol. Prog. Ser. 28, $299-302$.

Cederwall. H. \& Elmgren, R., 1980. Biomass increase of benthic macrofauna demonstrates eutrophication of the Baltic Sed. - Ophelid (Suppl.) 1, 287-304.

Cressie, N. A. C., 1991. Statistics for spatial data. Wiley, New York, $900 \mathrm{pp}$.

Cyberska, B, 1992. Thermohaline conditions. - Stud. Mat. oceanol. 61, 73-92.

Cyberska, B., Lauer, Z. \& Tr\%osinska, A., 1992. Environmental conditions in the Polish zone of the southern Baltic Sea during 1991. Institute of Meterology and Water Mandyement, Maritime Branch Materials. Gidynia. 257 pp.

Cyberska, B., Later, Z. \& Trzosinskd, A. 1993. Finvironmental conditions in the Polish zone of the southern Baltic Sea during 1992. Institute of Meterology and Water Management, Maritume Branch Materials, Gdynia, $256 \mathrm{pp}$.

Cyberski. J., 1992. River outflow from Poland - Stud. Mat. oceanol. 61, 53-66.

Fonselius, S. II., 1972. On eutrophication and pollution in the Baltic Sea. In: Marine pollution and sea life. Ed. by M. Ruivo. Fishing News Books, London, 23-28

Franck, H. \& Mat:t.dus, W., 2992. The absence of effective major intlows ind the present changes in the hydrographic conditions of the central Baltic deep water. - Proceedings of the 12 th Baltic Marıne Biologists Symposium, Helsinger, Denmark, 25-30 August 1991. Olsen \& Olsen, $53-60$.

Gargas, E., Dahl-Madsen, K. I., Schreder, 11. \& Rasmussen, J. 1978. Dynamics of Baltic ecosystems and causes of their variability. - Kieler Meeresforsch. (Sonderh.) 4, 210-232.

Gerlach, S. A., 1994. Oxygen conditions improve when the salinity in the Baltic Sea decreases. Mar. Pollut. Bull. 28, 413-416.

Gosselck, F., 1985. Untersuchungen am Makrozoobenthos des Arkonabeckens (südliche Ostsee). - Fischerei-Forsch. 23, 28-32.

Gosselck, F. \& Georgi, F. 1984. Benthic recolonization of the Lübeck Bdy (Western Baltic) in 1980/81. - Limnologica 15, 407--414.

Heip, C., 1995. Eutrophication and zoobenthos dynamics. - Ophelia 41, 113-136.

HE:LCOM, 1990. Second periodic assessment of the state of the marine environment of the Baltic Sea ared 1984-1988. Background Document. - Baltic Sed Environ. Proc. 35 B, 1-432.

Koine, B., 1995. Sedimentuntersuchungen in der Pommerschen Bucht. Dipl. Arb., Technische Fachhochschule Berlin, 50 pp.

Kube, J., 1992. Jas Makrozoobenthos des Windwatts am Bock - Szenario des Jahres 1991. Dipl. Arb., Univ. Rostock, $151 \mathrm{pp}$.

Kube, J., $1996 \mathrm{~d}$. Spatial and temporal variations in the population structure of the soft-shell clam. Mya arenaria, in the Pomeranian Bay (Southern Baltic Sea). - J. Sea Res. 35, 335-344.

Kube, J., 1996b. The ecology of macrozoobenthos and sea ducks in the Pomeranian Bay. Meereswiss Ber., Warnemünde 18,1-128. 
Kube, J., Powilleit, M. \& Warzocha, J., 1996. The importance of hydrodynamic processes and food availability for the structure of macrofauna assemblages in the Pomeranian Bay. - Arch. Hydrobiol. 138, 213-228.

Lampe, R., 1993. Environmental state and material flux in the western part of the Oder river estuary - results and consequences. - Petermanns geogr. Mitt. 137, 275-282.

Leipe, T., Neumann, T. \& Emeis, K.-C., 1995. Schwermetallverteilung in holozänen Ostseesedimenten. - Geowissenschaften 13, 470-478.

Löwe, F.-K., 1963. Quantitative Benthosuntersuchungen in der Arkonasee. - Mitt. zool. Mus. Berlin 39, 247-349.

Matthäus, W. \& Franck, H., 1992. Characteristics of major Baltic inflows - a statistical analysis. Cont. Shelf Res. 12, 1375-1400.

Matthäus, W. \& Lass, H.-U., 1995. The recent salt inflow into the Baltic Sea. - J. phys. Oceanogr. 25, $280-286$.

Messner, U. \& von Oertzen, J. A., 1991. Long-term changes in the vertical distribution of macrophytobenthic communities in the Greifswalder Bodden. - Acta Ichtyol. Pisc. 21 (Suppl.). $135-144$

Nakonieczny, J.. Ochocki, S. \& Renk, H., 1991. Long-term changes in primary production and chlorophyll concentrations in the Southern Baltic. - Acta Ichtyol. Pisc. 21 (Suppl.). 145-152.

Nehring, 1)., 1990. Die hỵdrographisch-chemischen Bedingungen in der westlichen und zentralen Ostsee im Jahre 1989. - FischForsch. 28, 35-44.

Nehring, D., Watthäus, W., Lass, H.-U. \& Nausch, G., 1994. Hydrographisch-chemische Zustandseinschärzung der Ostsee 1993. - Meereswiss. Ber., Warnemünde 7, 1-68.

Neumann, G. \& Bublitz. G., 1969. Seegrunduntersuchungen im westlichen Teif der ()der-Bucht. Beitr. Meeresk. 24/25, 81-109.

Pearson, T. H. \& Rosenberg, R., 1978. Macrohenthic succession in relation to organic enrichment and pollution of the marine environment. - Oreanogr. mar Biol. 16, 229-311.

Powilleit, M., Kube, J., Maslowski, J. \& Warzocha, J., 1995. Distribution of macrobenthic invertebrates in the Porneranian Bay (Southern Baltic Sea) in 1993/94. - Bull. Sea Fish. Inst. 3, $75-87$.

Prena. J., 1994. Oxygen depletion in Wismar Bay (Western Baltic Sea) 1988. - Arch. Fish. mar. Res. $42,77-87$.

Reise, K., Herre, E. \& Sturm, .W. 1989. Historical changes in the benthos of the Wadden Sed around the island of Sylt in the Vorth Sea. - Helgoländer Meeresunters. 43, 417-433.

Renk, 11., 1992. Primary production and the concentration of chlorophyll a. - Stud. Mat. oceanol. $61,167-180$

Rosenberg, R. \& Möller, P. 1979. Salinity stratilicated benthic macrofaunal communities and long. term monitoring along the west coast of Sweden. - J. exp. mar. Biol. Ecol. 37, 175-203.

Schulz, S. \& Kaiser, W., 1986. Increasing trends in plankton variables in the Baltic Sed - a further sign of eutrophication? - Ophelia (Suppl.) 4. 249-257

Trzosinska, A. \& Cyberska, B.. 1992. Oxygen and hydrogen sulphide.- Stud. Mat. oceanol. 61, 9.3-100.

Warzocha, J., 1995. Classification and structure of macrofaunal communities in the southern Baltic: - Arch. Fish. mar. Res. 42, 225-237.

Weigelt, M., 1991. Short- and long-term changes in the benthic community of the deeper parts of Kiel Bay (Western Baltic) due to oxygen depletion and eutrophication. - Meerestorschung 33. 297-311.

Weigelt, ..$\&$ Rumohr, H., 1986. Effects of wide-range oxygen depletion on benthic fauna and demersal fish in Kiel Bay 1981-1983. - Meeresforschung 31, 124-136 